\title{
PENGARUH DAYA DUKUNG PONDASI TIANG BETON BERTULANG BAMBU TERHADAP TANAH GAMBUT
}

\author{
Susy Srihandayani \\ Program Studi Teknik Sipil Sekolah Tinggi Teknologi Dumai \\ Jl. Utama Karya II Kelurahan Bukit Timah Dumai \\ E-mail : susys3unand18@gmail.com
}

\begin{abstract}
Abstrak
Berbagai kerugian dan kerusakan bangunan yang terjadi akibat kegagalan pondasi pada tanah sulit. Berbagai macam jenis pondasi pada tanah lunak telah diciptakan untuk mengatasi kegagalan tersebut, dengan nilai untuk sebuah pondasi bangunan relatif mahal. Oleh karena itu perlu dilakukan penelitian yang lebih baik untuk mengatasi masalah pondasi tersebut khususnya pada tanah gambut. Dalam penelitian ini mendisain sebuah pondasi yang bisa digunakan pada tanah gambut. Pondasi berbahan beton minimalis menggunakan tulangan bambu divariasikan menggunakan jumlah batang dan diameternya. Sampel pondasi beton di rancang di laboratorium, dan setelah umur beton tersebut mencukupi, dilakukan pengujian dilapangan dan diberikan beban secara vertikal. Selama pengujian dilakukan pencatatan beban secara vertikal diberikan dan penurunan yang terjadi. Dari pengujian dan analisis ini maka dapat dilihat kekuatan daya dukung dan penurunan pondasi di tanah gambut. Hasil penelitian ini diharapkan dapat menjadi salah satu solusi untuk menentukan pondasi, dan pemanfaatan bambu sebagai bahan penganti tulangan besi pada pondasi beton.
\end{abstract}

Kata Kunci : Pondasi Tiang,Tulangan Bambu, Daya Dukung, Tanah Gambut

\begin{abstract}
Various loss and damage to buildings that occur due to failure of foundations on difficult soils. Various types of soft soil foundations have been created to overcome these failures with values for a building foundation relatively expensive. Therefor it is necessary to do better research to overcome the problem of the foundation, especially on peat soil. In this study design a foundation that can be used on peat soil. The foundation made from minimalist concrete using bamboo reinforcement is varied using the number of stems and diameter. Concrete foundation samples are designed in the laboratory, and after the age of the concrete is sufficient, testing is carried out in the field and given a vertical load. During the test a vertical load recording is given and a decrease occurs. From this testing and analysis, it can be seen the strength of carrying capacity and the decrease in foundation on peat soil. The results of this study are expected to be one solution to determine the foundation, and utilization of bamboo as an iron reinforcement substitute material on concrete foundations.
\end{abstract}

Keywords : Pile Foundation, Bamboo Reinforcement, Bearing Capacity, Peat Soil 


\section{A. PENDAhULUAN}

Berbagai jenis bangunan sipil akan selalu berhubungan dengan tanah. Dengan mengetahui karakter suatu tanah, maka jenis pondasi yang akan digunakan dapat diketahui.

Sehingga kondisi tanah dasar harus sangat berpengaruh terhadap kestabilan dan keamanan konstruksi ang berada diatasnya. (Dharmayasa, 2014). Pondasi merupakan salah satu unsur pada suatu bangunan yang meneruskan beban ke tanah atau batuan yang ada dibawahnya.

Area tanah gambut terbesar di Indonesia banyak ditemukan di pulau pulau besar seperti Sumatera, Kalimantan dan Papua. (Tanjung MI, 2017). Karakteristik tanah gambut sangat buruk untuk pondasi bangunan, dimana kuat gesernya rendah, kadar air tinggi, potensi penurunannya besar dan penurunan terjadi dalam jangka waktu yang Panjang (Srihandayani S, 2017).

Seiring perkembangan teknologi, berbagai macam pondasi telah diciptakan, dari jenis pondasi dalam sampai pondasi dangkal. Pondasi dalam menggunangan beton bertulang yang biasa di gunakan untuk bangunan bangunan berat, sedangkan untuk bangunan sederhana menggunakan kayu mahang dan bakau sebagai cerocok kayu untuk menstabilkan tanah gambut yang berada di bawah pondasi. (Srihandayani S, 2018)

Selain penggunaan kayu mahang dan bakau, bambu banyak juga digunakan sebagai bahan bangunan, karena bambu merupakan material bangunan yang murah, mudah diperoleh, mudah dikerjakan sendiri oleh masyarakat terutama di daerah pedesaan, serta ramah lingkungan karena merupakan material alami yang dapat diperbarui. Selain itu dari hasil penelitian (Anandhita, 2017) Kuat tarik cukup tinggi pada bambu setara dengan kuat tarik baja lunak, sehingga dapat dimanfaatkan sebagai material pengganti tulangan baja beton. Sebelumnya masyarakat menganyam bilah bilah bambu menjadi sebuah bidang atau bentuk tertentu, sehingga menghasilkan berbagai macam jenis, pola dan motif yang beragam. Berdasarkan motif dan estetika anyaman bambu, muncul dugaan bahwa anyaman memiliki fungsi lain yang menarik untuk dikaji lebih lanjut, terutama dari sisi teknik atau engineering.

\section{B. TINJAUANPUSTAKA \\ 1. Tanah}

Tanah merupakan campuran butiran butiran mineral dengan atau tanpa kandungan organik. Dengan kocokan air, butiran tanah dapat terpisah satu sama lain. Material ini berasal dari pelapukan batuan, baik secara fisik maupun kimia. (Hardiayatmo, 1996).

Menurut Hakam 2008, material geologi yang berada pada bagian kerak bumi yang digunakan sebagai media bekerja atau untuk mendirikan bangunan diatasnya dapat juga disebut dengan tanah. Secara kimiawi, batuan dan tanah dapat mempunyai unsur yang sama, namun keduanya dibedakan berdasarkan sifat fisiknya.

\section{Tanah Gambut}

Tanah gambut di bagi berdasarkan sifat fisik dan kimiawinya, tanah gambut menurut Whitten dan Brooks 1978 mengemukakan bahwa tanah gambut atau peat adalah massa nabati yang terombak sebagian yang semula tumbuh dalam danau dangkal atau rawa. Adhi dan Suhardjo 1976, mengemukakan bahwa gambut terbentuk dari bahan asal yang terdiri atas sisa tanaman yang telah mati dan 
dilingkupi oleh keadaan lingkungan yang selalu terendam air, maka pelapukan tidak berlangsung normal dan sempurna, dengan demikian akan membentuk profil yang seluruhnya tersusun atas timbunan bahan organic dengan jeluk (dept) bervariasi mulai dari ketebalan $50-100 \mathrm{~cm}$ disebut dangkal, ketebalan $100-200 \mathrm{~cm}$ disebut gambut sedang, ketebalan $200-300 \mathrm{~cm}$ disebut gambut dalam, dan ketebalan lebih dari $300 \mathrm{~cm}$ disebut gambut sangat dalam.

\section{Karakteristik Tanah Gambut}

Notohadiprawiro, 1988 mengungkapkan bahwa daerah gambut berupa rawa rawa, dimana pada bagian atas lahan gambut biasanya terdapat tanaman hidup sehingga bagian atas lahan gambut tersebut banyak mengandung akar akar kecil tumbuhan. Soil Survei Staff 1951 dalam Notohadiprawiro, 1988, menyatakan bahwa tanah gambut pada umumnya berwarna coklat tua sampai kehitaman, meskipun bahan asalnya berwarna kelabu, coklat atau kemerah-merahan, tetapi setelah mengalami dekomposisi akan muncul senyawa-senyawa humik berwarna gelap. Whitten dan Brooks (1978, dalam Notohadiprawiro, 1988), menuliskan bahwa dalam keadaan kering tanah gambut sangat kering, berat isi tanah organik dibandingkan dengan tanah mineral sangat rendah yaitu $0.2-0.3 \mathrm{kN} / \mathrm{m}^{3}$ yang merupakan nilai umum bagi tanah organik yang telah mengalami dekomposisi lanjut sedangkan berat isi kering untuk tanah mineral $1.25-1.45 \mathrm{kN} / \mathrm{m}^{3}$

\section{Pondasi}

Istilah pondasi digunakan dalam teknik sipil untuk mendefenisikan suatu konstruksi bangunan yang berfungsi sebagai penopang bangunan dan meneruskan beban bangunan di atasnya (upper structure) ke lapisan tanah yang cukup kuat daya dukungnya. Struktur bawah sebagai pondasi juga secara umum dapat dibagi dalam dua jenis, yaitu pondasi dangkal dan pondasi dalam.

Pemilihan jenis pondasi ini tergantung kepada jenis struktur atas, apakah termasuk konstruksi beban ringan atau beban berat dan juga jenis tanahnya.

Beberapa jenis pondasi berdasarkan kedalaman tanah keras yaitu:

a. Pondasi dangkal yaitu pondasi yang mendukung beban secara langsung seperti pondasi telapak yang berdiri sendiri dalam mendukung kolom, Pondasi memanjang dan pondasi rakit. (raft foundation).

b. Pondasi Dalam

Pondasi dalam adalah pondasi yang meneruskan beban bangunan ke tanah keras atau batu yang terletak jauh dari permukaan, seperti :

1) Pondasi sumuran (Pier Foundation) yaitu pondasi pondasi yang merupakan peralihan antara pondasi dangkal dan pondasi tiang, digunakan bila tanah dasar yang kuat terletak pada kedalaman yang relative dalam.

2) Pondasi tiang (pile foundation), digunakan bila tanah pondasi kedalaman yang normal tidak mampu mendukung bebannya dan tanah kerasnya terletak pada kedalaman yang sangat dalam.

\section{Bambu}

Bambu adalah bahan bangunan dari tumbuhan bukan kayu berbentuk pembuluh dan beruas-ruas dapat digunakan untuk tujuan konstruksi bangunan, seperti tiang, pipa air, atap 
atau cerucuk stabilitasi tanah (Krisdianto, 2006).

Beberapa kelebihan bambu jika dipergunakan untuk komponen bangunan secara umum :

a. Dapat diperbarui (3-5 tahun sudah dapat ditebang).

b. Murah harganya serta mudah pengerjaannya karena tidak memerlukan tenaga terdidik, cukup dengan peralatan sederhana pada kegiatan pembangunan.

c. Mempunyai kekuatan tarik yang tinggi (beberapa jenis bambu melampaui kuat tarik baja mutu sedang), ringan, berbentuk pipa beruas sehingga cukup lentur untuk dimanfaatkan sebagai komponen bangunan rangka

d. Rumah dari bambu cukup nyaman ditempati.

e. Masa konstruksi cukup singkat sehingga biaya konstruksi menjadi murah.

\section{Beton}

Beton merupakan campuran atau kombinasi dari agregat halus dan agregat kasar (pasir, kerikil, batu pecah, atau jenis agregat lain) dengan semen, yang dipersatukan oleh air dalam perbandingan tertentu. Beton tidak menjadi padat karena air menguap, tetapi semen berhidrasi, mengikat komponen lainnya bersama dan akhirnya membentuk material seperti batu. Beton struktur relatife lebih tahan terhadap temperatur tinggi akibat kebakaran yang keruntuhannya tidak terjadi secara tiba-tiba.

Kapasitas beton struktur akibat kebakaran dipengaruhi oleh berbagai hal, seperti temperatur tertinggi yang pernah dialami, lama kebakaran, proses pemadaman, jenis dan perilaku pembebanan, jenis dan ukuran agregat, dan factor air semen. (Oroh, dkk., 2003).

\section{Analisis Daya Dukung Pondasi Tiang}

Kapasitas daya dukung pondasi tiang dapat diestimasi dengan menggunakan persamaan sederhana sebagai penjumlahan dari daya dukung batas ujung tiang dan daya dukung sisi. Dari sejumlah metode yang dikembangkan untuk memprediksi daya dukung ultimit (batas) yang disumbangkan oleh ujung tiang, sebagian besar masih mengacu pada formulasi yang dikembangkan oleh Terzaghi untuk pondasi dangkal.

Kapasitas daya dukung ujung pondasi tiang dalam satuan gaya dapat dituliskan sebagai berikut:

$$
\begin{aligned}
& Q_{p}=A_{p} \cdot q_{p} \\
& \quad \text { dengan } q_{p}=c N_{c} *+q^{\prime} N_{q}
\end{aligned}
$$

Dimana,

$\mathrm{c}=$ nilai kohesi tanah dibawah dasar (ujung) pondasi

$q^{\prime}=\gamma^{\prime} \mathrm{L}$

q'= tegangan efektif tanah akibat berat diatas ujung tiang

$\gamma^{\prime}=$ berat volume tanah efektif diatas dasar pondasi

$\mathrm{L}=$ panjang tiang yang tertanam dalam tanah

$\mathrm{N}_{\mathrm{c}}{ }^{*}$ dan $\mathrm{N}_{\mathrm{q}} *$ adalah faktor kapasitas daya dukung tanpa satuan. (nondimensional) yang didapatkan hanya dari nilai sudut geser dalam tanah, $\phi$.

Beberapa metode yang digunakan untuk menentukan daya dukung pondasi.

a. Metode Mayerhoff

Menurut mayerhof, nilai faktor kapasitas daya dukung meningkat sejalan dengan meningkat nya nilai rasio kedalaman penanaman dan diameter pondasi (Lb/B) dan mencapai nilai maksimum pada nilai rasio (Lb/B) sekitar 0.5 $(\mathrm{Lb} / \mathrm{B})$. Untuk itu, perlu dilakukan 
penyesuaian (pembuatan kurva) nilai maksimum faktor kapasitas daya dukung $\mathrm{Nc}$ dan Nq. Nilai tersebut masih menyerupai seperti yang di usulkan terzaghi dimana variasi nilai faktor daya dukung tergantung dari hanya sudut geser dalam tanah. Perlu di ingat bahwa nilai faktor kapasitas daya dukung $\mathrm{Nc}$ dan $\mathrm{Nq}$ yang di berikan pada gambar adalah merupakan angka maksimum pada sebuah estimasi sistem tiang pondasi menurut mayerhof.

b. Metode Lamda $\lambda$

Prosedur perhitungan kapasitas daya dukung ujung yang melibatkan lebih banyak parameter tanah di usulkan oleh Vijayvergiya dan Focht (1972). Kapasitas yang diusulkan di ekspresikan sebagai berikut :

$$
\mathrm{qs}=\lambda\left(\mathrm{q}^{\prime}+2 \mathrm{cu}\right)
$$

dimana

$\lambda=$ Koefisien gesekan tiang.

$\mathrm{c}_{\mathrm{u}} \quad=$ Parameter kohesi tanah

q' =Tekanan tanah efektif pada kedalaman yang ditinjau

Sebagai gambaran untuk menentukan faktor - faktor kapasitas daya dukung $\lambda$, dibuatkan grafik hubungan kedalaman (m) dengan koefisien gesekan $(\lambda)$. Hakam 2008

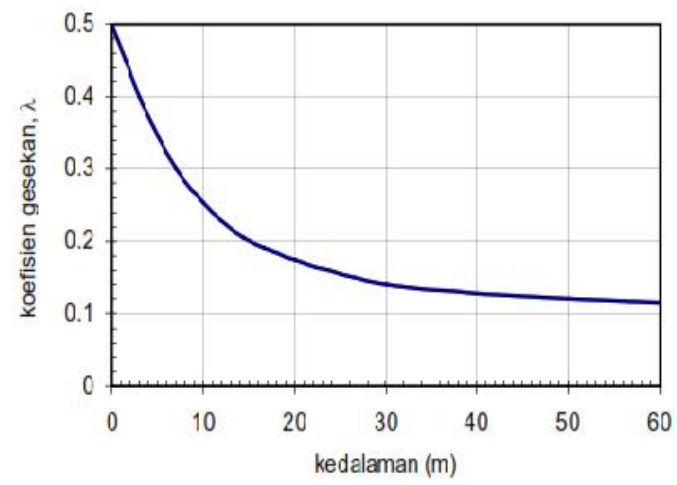

Gambar 1. Koefisien gesekan $(\lambda)$ Hakam 2008

\section{METODE PENELITIAN}

\section{Lokasi Penelitian}

Penyelidikan dilakukan di laboratorium Teknologi Beton dan Mekanika Tanah Program Studi Teknik Sipil Sekolah Tinggi Teknologi Dumai.

\section{MetodePenelitian}

Metode yang diterapkan dalam penelitian ini adalah eksperimen di laboratorium dan lapangan. Pengujian dilakukan berawal dari penyelidikan propertis tanah, pengujian kuat tekan beton rencana K250 benda uji tiang bertulang bambu dengan Diameter $0.1 \mathrm{M}$, Panjang tiang $(\mathrm{L})=3 \mathrm{M}$. Pengujian daya dukung pondasi tiang, untuk tiang tunggal dan tiang grup $(2 \times 2)$ dengan melakukan pembebanan secara vertikal di lapangan.

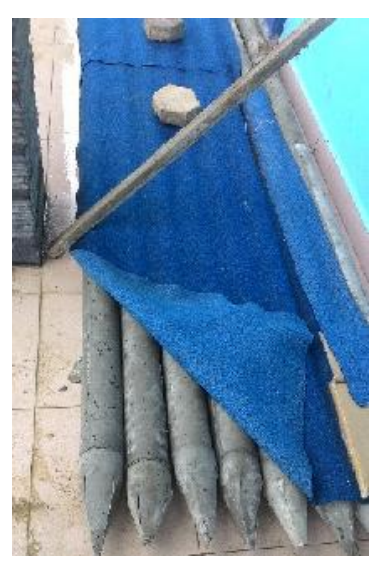

Gambar 2. Tiang bertulang bambu

\section{Rumus atau Persamaan}

Menghitung daya dukung ujung tiang menggunakan metode Mayerhoff sesuai dengan persamaan :

$$
Q_{p}=A_{p} \cdot q_{p}
$$

Dengan $q_{p}$ memakai persamaan

$$
q_{p}=c N_{c} *+q^{\prime} N_{q} *
$$


Menentukan nilai maksimum factor daya dukung dengan menggunakan grafik Mayerhoff, $\mathrm{Nq}^{*}$ dan $\mathrm{Nc}^{*}$

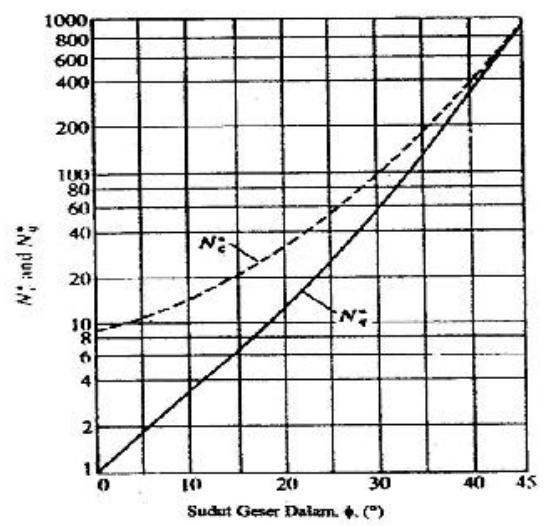

Gambar 3. Nilai factor daya dukung Nq* dan Nc* (Hakam 2008)

\section{HASIL DAN EMBAHASAN}

\section{Hasil Penelitian dan perhitungan secara teoritis}

\section{Data Pondasi :}

Diameter tiang, $\mathrm{B}=0.1 \mathrm{~m}$

Panjang, $\mathrm{L} \quad=3 \mathrm{~m}$

Spasi, $\mathrm{S} \quad=0.2 \mathrm{~m}$

Jumlah tiang memanjang, $\mathrm{m}=2$

Jumlah tiang melebar, $\mathrm{n}=2$

\section{Data propertis tanah :}

Berat Volume, $\gamma=0.94 \mathrm{t} / \mathrm{m}^{3}$

Sudut geser dalam, $\phi=21.06^{\circ}$

Kohesi, $\mathrm{c} \quad=0.002354 \mathrm{t} / \mathrm{m}^{2}$

\section{a. Daya dukung tiang tunggal}

Jika sudut geser dalam yang didapat dalam penelitian tanah $(\phi=21,06)$

Maka didapat Nilai $\mathrm{Nq}^{*}=16$ dan $\mathrm{Nc}^{*}=37$ dari gambar 3 diatas.

Nilai tekanan tanah vertikal effektif , q' pada kedalaman 3,0 m maka:

$$
\begin{aligned}
q^{\prime} & =q_{3 m}^{\prime}=\gamma L \\
& =0,94 \text { ton } / m^{3} \times 3 \mathrm{~m} \\
& =2,82 \text { ton } / m^{2}
\end{aligned}
$$

Selanjutnya ,

$$
\begin{aligned}
q_{p}= & 0,002354 \mathrm{t} / m^{2} \times 37+2,82 \\
& \operatorname{ton} / m^{2} \\
= & 45,1 \mathrm{t} / m^{2}
\end{aligned}
$$

Luas penampang ujung tiang, Ap

$$
A_{p}=\frac{1}{4} x \pi B^{2}=0,0079 \mathrm{~m}^{2}
$$

Daya dukung ujung ultimit, Qp

$$
\begin{aligned}
\mathrm{Qp} & =A_{p} \cdot q_{p} \\
& =0,0079 \mathrm{~m}^{2} \times 45,1 \mathrm{t} / \mathrm{m}^{2} \\
& =0,35 \text { ton }
\end{aligned}
$$

Daya dukung sisi (Metoda $\lambda$ )

Jika kohesi ( $\left.\mathrm{c}=0,002 \mathrm{t} / \mathrm{m}^{2}\right)$ yang di dapatkan dari hasil penelitian tanah gambut, maka di dapat hasil $\mathrm{Cu}$ dari perhitungan :

$$
\begin{aligned}
\mathrm{Cu} & =\mathrm{c} \times 9,81 \\
& =0,002 \mathrm{t} / \mathrm{m}^{2} \times 9,81 \mathrm{~m} / \mathrm{d}^{2} \\
& =0,023 \mathrm{kN} / \mathrm{m}^{2}
\end{aligned}
$$

Didapat, $\lambda=0,40$

Luas Bidang kontak, As

As $=\pi \times \mathrm{B} \times \mathrm{L}$

$=3,14 \times 0,1 \mathrm{~m} \times 3 \mathrm{~m}$

$=0,942 m^{2}$

Tahanan sisi, qs

$$
\begin{aligned}
q_{s} & =\lambda\left(q^{\prime}+2 C\right) \\
& =0,40 \times(0,0002820+2(0,023) \\
& =1 / m^{2} \\
& 1,1296 \mathrm{t} / \mathrm{m}^{2}
\end{aligned}
$$

Kapasitas daya dukung sisi, Qs

$$
\begin{aligned}
\text { Qs } & =\text { As . } q_{s} \\
& =0,942 m^{2} \times 1,1296 \mathrm{t} / \mathrm{m}^{2} \\
& =1,06 \text { ton }
\end{aligned}
$$

Kapasitas daya dukung tiap tiang, Qu

$$
\begin{aligned}
\mathrm{Qu} & =\mathrm{Qp}+\mathrm{Qs} \\
& =0,35 \text { ton }+1,06 \text { ton } \\
& =1,418 \text { ton }
\end{aligned}
$$

Kapasitas dukung sisi yang diizinkan, (Qa)

$$
\begin{aligned}
\mathrm{Qa} & =\mathrm{Qu} / \mathrm{SF} \\
& =1,418 \text { ton } / 3 \\
& =0.47 \text { ton } \\
\mathrm{SF} & =\text { diambil } 3
\end{aligned}
$$




\section{b. Daya dukung tiang tunggal}

Daya dukung tiang grup ditentukan oleh daya dukung tiap-tiap tiang dan susunan tiang-tiang tersebut dalam sebuah grup.

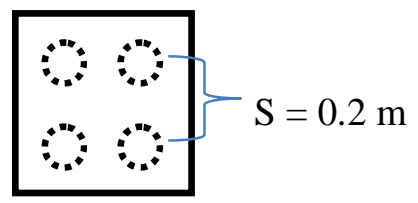

Gambar 4. Susunan tiang grup

$$
\text { Lebar grup , } \mathrm{Bg}
$$

$$
\begin{aligned}
\mathrm{Bg} & =(\mathrm{n}-1) \mathrm{Sn}+\mathrm{B} \\
& =(2-1) \times 0,2 \mathrm{~m}+0,1 \mathrm{~m} \\
& =0,3 \mathrm{~m}
\end{aligned}
$$

Panjang grup ,Lg

$$
\begin{aligned}
\mathrm{Lg} & =(\mathrm{m}-1) \mathrm{Sm}+\mathrm{B} \\
& =(2-1) \times 0,2 \mathrm{~m}+0,1 \mathrm{~m} \\
& =0,3 \mathrm{~m}
\end{aligned}
$$

Effesiensi tahanan ujung, $E_{y, p}$

$$
\begin{aligned}
E_{y, p} & =\frac{B_{y} \cdot L_{y}}{m \cdot n \cdot A_{p}} \\
& =\frac{0,3 m \times 0,3 m}{2 \times 2 \times 0,0 m^{2}} \\
& =2,8662>1 \text { maka diambil } \\
E_{g, p} & =1
\end{aligned}
$$

Effesiensi tahanan sisi,$E_{g, s}$

$$
\begin{aligned}
E_{y, s} & =\frac{2\left(B_{y}+L_{y}\right)}{m \cdot n \cdot \Theta} \\
& =\frac{2(0,3 m+0,3 m)}{2 \times 2 \times(\pi 0,1 m} \\
& =0,9554<1
\end{aligned}
$$

maka diambil

$$
E_{y, s}=0,9554
$$

Menentukan tahanan ujung dan tahanan sisi sebagai berikut :

$$
\begin{aligned}
\text { Qp, grup } & =E_{g, p} \times Q \quad(m \times n) \\
& =1 \times 0,3543 \text { ton } \times 2 \times 2 \\
& =1,417 \text { ton } \\
\text { Qs, grup } & =E_{y, \mathrm{~s}} \times Q \quad(m \times n) \\
& =0,9554 \times 1,06 \text { ton } \times 2 \times 2 \\
& =4,066 \text { ton }
\end{aligned}
$$

Nilai kapasitas daya dukung total adalah penjumlahan dari keduannya, yaitu :

$$
\begin{aligned}
\mathrm{Qu}, \text { grup } & =\mathrm{Qp}, \text { grup }+\mathrm{Qs}, \text { grup } \\
& =1,417 \text { ton }+4,066 \text { ton } \\
& =5,483 \text { ton } \\
\mathrm{Qa}, \text { grup } & =\mathrm{Qu} / \mathrm{SF} \\
& =5,483 \text { ton } / 3 \\
& =1,827 \text { ton. } \\
\mathrm{SF} & =\text { diambil } 3
\end{aligned}
$$

\section{c. Hasil Penelitian dan pengujian di lapangan}

Berdasarkan pengujian pembebanan dilapangan pada tiang bertulang bambu didapat besar penurunan sebagai berikut :

Tabel 1. Hasil pengujian penurunan

\begin{tabular}{cccc}
\hline \multicolumn{4}{c}{ Tiang tunggal } \\
Load & $\begin{array}{c}\text { Penurunan } \\
\mathrm{mm}\end{array}$ & $\begin{array}{l}\text { Tiang Grup } \\
\text { Load }\end{array}$ & $\begin{array}{c}\text { Penurunan } \\
\mathrm{Kg}\end{array}$ \\
$\mathrm{Kg}$ & 0 & 300 & 0,20 \\
0 & 10 & 600 & 0,85 \\
100 & 30 & 900 & 1,68 \\
200 & 50 & 1200 & 2,18 \\
300 & 60 & 1500 & 2,40 \\
400 & 75 & 1800 & 3,99 \\
500 & 100 & & \\
600 & &
\end{tabular}

(Sumber : Hasil pengujian lapangan, 2018) 


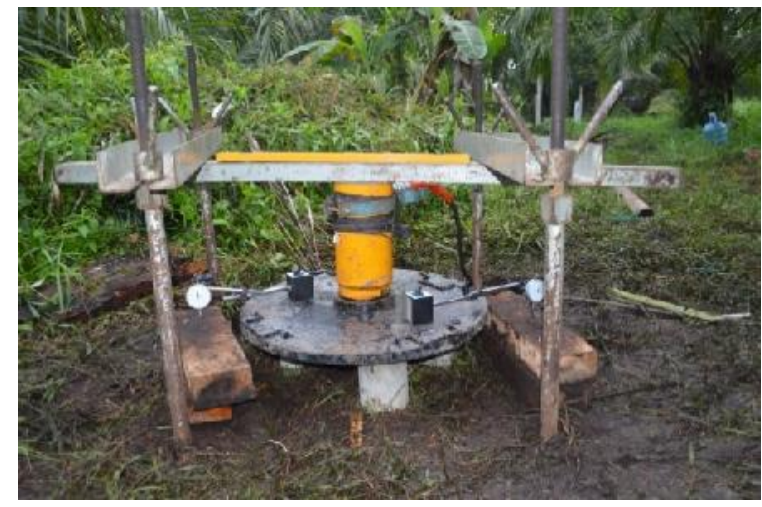

Gambar 5. Pengujian penurunan tiang grup

\section{Pembahasan}

Dari hasil pengujian yang telah dilakukan di lapangan terhadap pondasi, didapatkan kesimpulan bahwa analisa daya dukung ultimit yang menggunakan teori klasik sebanding nilainya dengan hasil yang didapatkan dari data lapangan. Pembebanan yang dilakukan pada tiang tunggal sebesar $\mathrm{P}_{\max }=600$ $\mathrm{kg}$, penurunan yang terjadi sebesar $=10$ $\mathrm{cm}$. Sedangkan pada tiang grup, pembebanannya sebesar $\mathrm{P}_{\max }=1800 \mathrm{~kg}$ dan penurunan yang terjadi sebesar $0,399 \mathrm{~cm}$. Sedangkan kapasitas daya dukung yang diizinkan menggunakan rumus Mayerhoft dengan metode $\lambda$ pada tiang tunggal sebesar $470 \mathrm{~kg}$, dan pada ting grup sebesar $1827 \mathrm{~kg}$.

\section{E. KESIMPULAN}

Kesimpulan yang didapat dari penelitian ini yaitu pondasi yang direncanakan mampu untuk menahan beban yang bekerja secara vertikal untuk bangunan sederhana, jumlah tiang beton bertulang bambu disesuaikan dengan beban yang diberikan dan tergantung jenis bangunan yang berada diatasnya. Pondasi ini di disain khusus untuk tanah daya dukung rendah.

\section{DAFTAR PUSTAKA}

Anandhita G., 2017, Anyaman Bambu sebagai Tulangan Panel Beton Pracetak

Hakam A., 2008, Teknik Pondasi; Untuk Mahasiswa dan Praktisi, Bintang Grafika, Padang.

Srihandayani S., 2017, Korelasi Insitu CBR Test terhadap Daya Dukung Tanah Ekspansif dengan Perkuatan Anyaman Bambu, Prosiding Seminar Nasional Sekolah Tinggi Teknologi Dumai 1 (1)

Srihandayani S., 2017, Pengaruh Tanah Ekspansif pada Bangunan Sipil dan Solusinya, Jurnal Unitek Vol. 10 Sekolah Tinggi Teknologi Dumai 1 (1)

Srihandayani S., 2018, Bearing capacity of floating foundations used PVC (Poly Vinyl Chloride) on soft soil with the scale, International Journal of Engineering and Technology (UAE) Vol 7, Issue: 2.5 Special Issue 5 